\title{
JiMAWAbdi :-
}

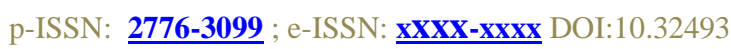
Jurnal Ilmiah Mahasiswa Mengabdi (JIMA WAbdi) Volume 1 Nomor 1, April 2021 (11 - 16)

http://openjournal.unpam.ac.id/index.php/JMAb/index

\section{Meningkatkan Motivasi Belajar Dimasa Pandemic}

\author{
Septia Wulandari' ${ }^{1}$, Ria Apriyani Rahayu², Cindy Nurlita ${ }^{3}$, Adhitya Julianto ${ }^{4}$, \\ Muhammad Ilyas ${ }^{5}$, Jeni Andriani ${ }^{6 *}$ \\ 1,2,3,4,5 Mahasiswa Manajemen, Universitas Pamulang; septiawlnd01@ gmail.com ${ }^{1}$ \\ ${ }^{6}$ Fakultas Ekonomi, Universitas Pamulang; dosen00436@unpam.ac.id*
}

Received 08 April 2021| Revised 15 April 2021 | Accepted 21 April 2021

*Korespondensi Penulis

\begin{abstract}
Abstrak
Fenomena pendidikan pada masa pendemi yang diharapkan orang tua, bahwa pendidikan anak haruslah dapat memperhatikan dan mengoptimalkan prestasi pendidikan anak. Kebutuhan ini tercapainya prestasi yang lebih baik tidak terlepas adanya peranan motivasi belajar yang baik bagi anak. Karenanya sangat dibutuhkan peranan dalam menumbuhkan dan memberikan motivasi agar siswa melakukan aktivitas belajar semakin lebih baik dan semakin meningkat. Tujuan kegiatan pengabdian ini untuk membantu meningkatkan motivasi belajar siswa dalam meningkatkan prestasi belajar dimasa pandemic di Yayasan Alabqo Amanah Marwah. Metode pelaksanaan PKM berupa presentasi materi meningkatkan motivasi belajar dimasa pandemic dan tanya jawab dengan peserta siswa Yayasan Alabqo Amanah. Hasil pengabdian ini menunjukkan bahwa siswa sangat antusias mengikuti kegiatan PKM dan dapat meningkatkan motivasi belajar syang tinggi dalam mencaai cita-cita yang akan datang.
\end{abstract}

Kata Kunci: Motivasi belajar; Prestasi; Pandemic

\begin{abstract}
The phenomenon of education during a pandemic is expected by parents, that children's education must be able to pay attention to and optimize children's educational achievement. This need to achieve better achievement is inseparable from the role of good learning motivation for children. Therefore, a role is needed in growing and providing motivation so that students carry out learning activities that are getting better and increasing. The purpose of this service activity is to help increase student motivation in improving learning achievement during the pandemic at the Alabqo Amanah Marwah Foundation. The method of implementing PKM in the form of material presentation increases learning motivation during the pandemic and questions and answers with the students of the Alabqo Amanah Foundation. The results of this service show that students are very enthusiastic about participating in PKM activities and can increase learning motivation which is very high in achieving future goals.
\end{abstract}

Keywords: motivation to learn; Achievement; Pandemic

\section{PENDAHULUAN}

Motivasi belajar merupakan keseluruhan daya penggerak dalam diri siswa yang menimbulkan kegiatan belajar, yang menjamin kelangsungan dari kegiatan belajar dan memberikan arah pada kegiatan belajar, sehingga tujuan yang dikehendaki oleh subyek belajar itu dapat tercapai (Sardiman, 1986: 75). Setiap siswa membutuhkan motivasi belajar untuk menjalankan visi dan misi dalam mencapai cita cita. Oleh sebab itu, orang tua harus selalu mengawasi dan memberi motivasi dalam belajar agar anak anak dapat belajar dengan senang hati dan tidak membosankan. Karena memberikan semangat belajar ataupun motivasi tidak lah mudah, bagi sebagian orang tua yang sibuk dalam mengurus pekerjaannya sendiri maka orang tua tersebut harus 
memberikan fasilitas dengan memberikan bimbingan untuk siswa tersebut. Pentingnya motivasi belajar dalam siswa sangat penting diantaranya melibatkan siswa, orang tua dan guru. Konsentrasi saat belajar merupakan nilai tambah dalam belajar, stategi yang dapat mengarahkan siswa kedalam gapaian cita cita akan menjadi point penting untuk masa depan dan memicu keberhasilan. Saat belajar biasanya banyak anak remaja ataupun anak muda yang tidak mempunyai waktu yang terarah baik itu dalam memaksimalkan waktu belajar dalam kehidupan sehari-hari

Berdasarkan latar belakang tersebut, kami dari Tim Program Pengabdian Kepada Masyarakat (PKM) Universitas Pamulang (UNPAM) yang berjumlah 5 Mahasiswa terpanggil untuk ikut serta membantu agar memiliki motivasi dalam belajar yang terarah dengan baik dan tepat dan tidak membuangbuang waktu dengan percuma.

Tabel 1. Ketercapaian Target Luaran

\begin{tabular}{|c|c|c|c|}
\hline $\mathrm{NO}$ & TUJUAN & TARGET & KETERCAPAIAN \\
\hline 1 & $\begin{array}{lr}\text { Memberi } & \text { pemahaman } \\
\text { tentang } & \text { meningkatkan } \\
\text { motivasi } & \text { belajar dimasa } \\
\text { pandemic } & \end{array}$ & $\begin{array}{l}\text { Yayasan Alabqo Amanah } \\
\text { Marwah yang bertempat di jalan } \\
\text { Lingkar Selatan rt/rw 013/005, } \\
\text { Kranggan, Setu, Tangerang bisa } \\
\text { memahami bagaimana penting- } \\
\text { nya motivasi belajar dimasa } \\
\text { pandemic }\end{array}$ & $\begin{array}{l}\text { Materi } 1 \text { tersampaikan, siswa bisa } \\
\text { memahami bagaimana pentingnya } \\
\text { motivasi belajar dimasa pandemic }\end{array}$ \\
\hline 2 & $\begin{array}{l}\text { Memberi pemahaman } \\
\text { wawasan kepada siswa } \\
\text { yayasan alabqo amanah yang } \\
\text { bertempat di jalan lingkar } \\
\text { selatan rt/rw 013/005, } \\
\text { Kranggan, Setu, Tangerang, } \\
\text { agar semakin meningkatkan } \\
\text { motivasi belajar. }\end{array}$ & $\begin{array}{l}\text { Siswa Yayasan Alabqo Amanah } \\
\text { Marwah, jalan Lingkar Selatan } \\
\text { RT/RW 013/005, Kranggan, } \\
\text { Setu, Tangerang, memahami } \\
\text { bagaimana pentingnya motivasi } \\
\text { belajar dimasa pandemi. }\end{array}$ & $\begin{array}{l}\text { Materi ke } 2 \text { tersampaikan, kepada } \\
\text { siswa Yayasan Alabqo Amanah } \\
\text { Marwah di jalan Lingkar Selatan } \\
\text { rt/rw 013/005, Kranggan, Setu, } \\
\text { Tangerang, bisa memahami bagai- } \\
\text { mana motivasi belajar yang } \\
\text { dilakukan dalam kehiduapan sehari } \\
\text { hari agar giat belajar. }\end{array}$ \\
\hline
\end{tabular}

Melihat situasi seperti ini, meyakinkan kepada pelajar bahwa motivasi itu sangat penting, sebab adanya motivasi mereka dapat meningkan minat belajar untuk menggapai cita cita mereka. Pengurus yayasan lebih memperhatikan perkembangan minat dan bakat mereka, sebab dengan cara tersebut mereka dapat menenutukan arahan untuk mencapai cita cita mereka.

\section{Pengertian Motivasi dan Motivasi Belajar}

Motivasi adalah usaha yang didasari untuk mengerahkan dan menjaga tingkah seseorang agar ia terdorong untuk bertindak melakukan sesuatu sehingga mencapai hasil atau tujuan tertentu. Motivasi belajar merupakan salah satu faktor yang turut menentukan keefektifan dalam pembelajaran. Seorang peserta didik akan belajar dengan baik apabila ada faktor pendorongnya yaitumotivasi belajar. Peserta didik akan belajar dengan sungguh-sungguhjika memiliki motivasi belajar yang tinggi.

Menurut Hamzah B. Uno (2011: 23) "motivasi belajar adalah dorongan internal dan eksternal pada siswa yang sedang belajar untuk mengadakan tingkah laku, pada umumnya dengan beberapa indicator atau unsur-unsur yang mendukung. Indikator-indikator tersebut, antara lain: adanya hasrat dan keinginan berhasil, dorongan dan kebutuhan dalam belajar, harapan dan cita-cita masa depan, penghargaan dalam belajar, dan lingkungan belajar yang kondusif."

Selain itu, Winkel (2005: 160), menyebutkan motivasi belajar adalah keseluruhan daya penggerak psikis didalam siswa yang menimbulkan kegiatan belajar itu demi mencapai suatu tujuan. Sejalan dengan pendapat di atas, Sardiman A. M (2007: 75), menjelaskan motivasi belajar adalah seluruh daya penggerak didalam diri siswa yang 
menimbulkan kegiatan belajar yang menjamin kelangsungan dari kegiatan belajar yang memberikan arah pada kegiatan belajar sehingga tujuan yang dikehendaki oleh subjek belajar itu dapat dicapai."

Dari beberapa pendapat di atas dapat disimpulkan bahwa motivasi belajar adalah seluruh daya penggerak psikis yang ada dalam diri individu siswa yang dapat memberikan dorongan untuk belajar demi mencapai tujuan dari belajar tersebut.

\section{Peran Dan Fungsi Motivasi Belajar}

Menurut Hamzah B. Uno (2011: 27-29), peran penting motivasi belajar dan pembelajaran, antara lain:

1. Peran motivasi belajar dalam menentukan penguatan belajar.

Motivasi dapat berperan dalam penguatan belajar apabila seorang anak yang sedang belajar dihadapkan pada suatu masalah yang menentukan pemecahan dan hanya dapat dipecahkan berkat bantuan hal-hal yang pernah dilalui.

2. Peran motivasi dalam memperjelas tujuan belajar.

Peran motivasi dalam memperjelas tujuan belajar erat kaitannya dengan kemaknaan belajar. Anak akan tertarik untuk belajar sesuatu, jika yang dipelajari itu sedikitnya sudah dapat diketahui atau dinikmati manfaatnya oleh anak.

3. Motivasi menentukan ketekunan belajar.

Seorang anak yang telah termotivasi untuk belajar sesuatu berusaha mempelajari dengan baik dan tekun dengan harapan memperoleh hasil yang lebih baik.

Selain itu, Oemar Hamalik (2011: 108), menyebutkan fungsi motivasi itu meliputi:

1. Mendorong timbulnya kelakuan/ suatu perbuatan.

2. Motivasi berfungsi sebagai pengarah, artinya mengarah pada perbuatan ke pencapaian tujuan yang diinginkan.

3. Motivasi berfungsi sebagai penggerak, artinya sebagai motor penggerak dalam kegiatan belajar.
Dari pendapat di atas dapat disimpulkan bahwa peran dan fungsi motivasi belajar adalah sebagai pendorong usaha dan pencapaian prestasi sehingga untuk mencapai prestasi tersebut peserta didik dituntut untuk menentukan sendiri perbuatan-perbuatan apa yang harus dilakukan untuk mencapai tujuan belajarnya

\section{METODE}

Perencanaan agar program ini berjalan secara maksimal, maka diperlukan perencanaan secara tepat diantaranya menyusun proposal kegiatan sosialisasi dalam meningkatkn motivasi belajar diamasa pandemic, mengetahui manfaat yang ada jika para pelajar ikut andil dan analisis keaktifan mereka untuk menggapai cita cita mereka, menyusun waktu pelaksanaan kegiatan, meminta izin kepada pihak yang berwenang dengan menghubungi ketua yayasan yang telah bersedia menyediakan sarana kegiatan, mempersiapkan alat dan bahan dalam memberikan sosialisasi, mempersiapkan daftar pihak yang hendak dijadikan sebagai peserta PKM di Yayasan Alabqo Amanah Marwah.

Metode kegiatan yang dilakukan dalam rangka menyukseskan kegiatan pengabdian ini, yaitu:

1. Peralatan yang dibutuhkan untuk melaksanan kegiatan ini. Pada tahapan ini pelaksana memulai dengan melakukan koordinasi dengan instansi terkait.

2. Penentuan Lokasi. Pada tahap ini dilakukan kunjungan ke lokasi untuk menentukan tempat (lokasi). Dalam memilih lokasi, kami mempertimbangkan dengan jarak yang kami tempuh dari Universitas ke lokasi pengabdian.

3. Perancangan kebutuhan.

Adapun tahapan yang dilakukan dalam perancangan kebutuhan secara berurutan adalah sebagai berikut:

a. Perancangan materi dalam meningkatkan pengetahuan tentang Motivasi Belajar, fungsi dan peran Motivasi Belajar, tips dan trik motivasi belajar, serta factor yang mempengaruhi motivasi belajar 
b. Perancangan materi untuk memahami bentuk-bentuk serta peran penting motivasi agar dapat mengelola waktu yang terarah dalam kehidupan seharihari.

c. Perancangan alat. Perancangan alat yang dibutuhkan meliputi: infokus, kertas materi, laptop

Metode pendekatan yang digunakan dalam kegiatan ini adalah :

1. Persentasi

2. Tanya Jawab

3. Games

4. Diskusi/sharing

\section{Waktu dan Tempat}

Kegiatan ini dilaksanakan pada bulan maret di Yayasan Alabqo Amanah Marwah Jalan Lingkar Selatan RT/RW 013/005, Kranggan, Setu, Tangerang, Banten 15312

\section{HASIL DAN PEMBAHASAN}

Pada Sabtu. 13 Maret 2021 telah diadakan kegiatan Pengabdian Kepada Masyarakat (PKM) di yayasan Albqo Amanah Marwah, Kranggan, Setu, Tangerang, Banten. Kegiatan ini dilakukan oleh mahasiswa program studi Manajemen, dan didampingi oleh dosen pembimbing ibu Jeni Andriani, S.S.,S.E.,M.M., Universitas Pamulang. Meskipun dalam kondisi pandemi covid 19, tidak menghalangi mahasiswa/i Unpam untuk melaksanakan PKM sesuai dengan protokol kesehatan yang berlaku.

Mahasiswa Pamulang yang diketuai oleh Adhitya Julianto bersama anggota nya yang terdiri dari Septia Wulandari, Ria Apriyani Rahayu, Cindy Nurlita dan Muhammad Ilyas sesuai dengan tema yakni "Meningkatkan Motivasi Belajar Di Masa Pandemic" mengajak anak-anak agar memotivasi diri mereka agar dapat menggapai cita cita mereka.

Kedatangan Tim PKM dari Prodi Manajemen Universitas Pamulang disambut baik oleh kak Sisca selaku pengurus Bina Yatim dan Dhuafa Yayasan Alabqo Amanah Marwah . Beliau berharap jika keadaan sudah kembali normal maka PKM harus dilaksanakan dengan sebaik dan semaksimal mungkin, mudahan tahun depan kondisi Negara yang kita cintai Indonesia terbebas dari wabah Virus Covid-19, sehingga kegiatan PKM yang dilaksanakan dapat memberikan ilmu baru yang bermanfaat khususnya kepada seluruh anak anak yayasan alabqo amanah.

Dalam pelaksanaanya, tim PKM mahasiswa memberikan motivasi kepada anak yatim terkait motivasi belajar. Mereka mengikuti PKM ini dengan semangat dan antusiasme yang tinggi karena mereka membuthkan tips dan trik untuk memotivasi diri mereka sendiri. Septia Wulandari, Ria Apriyani Rahayu dan Cindy Nurlita selaku pemateri dalam kegiatan ini memberikan penjelasan tentang motivasi belajar dimasa pandemic kepada seluruh anak yatim yang berjumlah sekitar 12 orang. Memberikan pemahaman serta cara agar mereka dapat belajar dengan giat dimasa pandemic ini. Disamping itu, setelah penjelasan materi, anak-anak diberika games agar tidak merasa bosan yang diberikan oleh tim PKM.

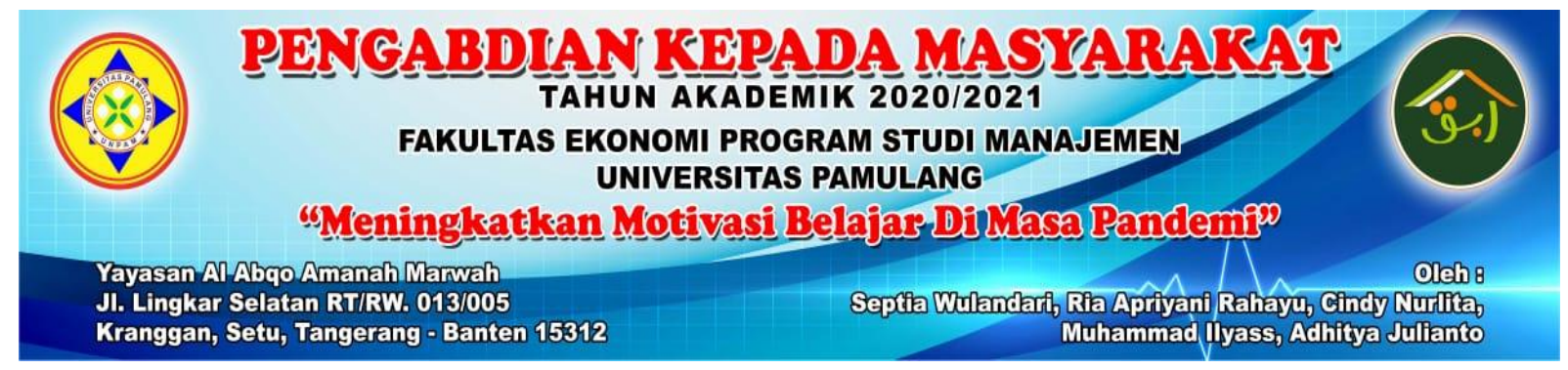

Gambar 1. Banner kelompok pelaksana PKM mahasiswa Universitas Pamulang 


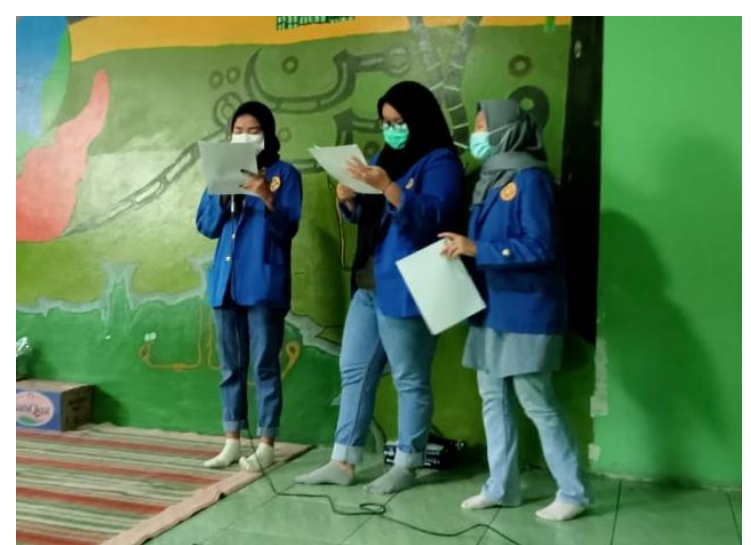

Gambar 2. Pemberian materi oleh mahasiswa Universitas Pamulang

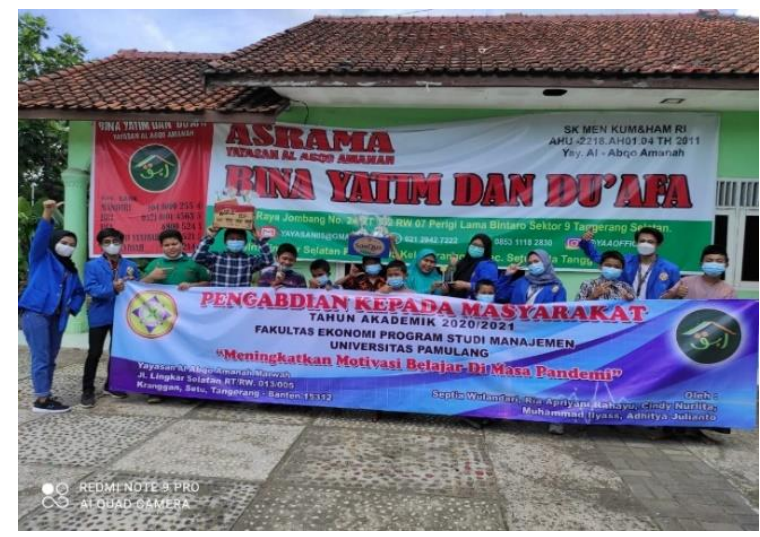

Gambar 3. Pelaksanaan PKM Universitas Pamulang dilakukan secara offline

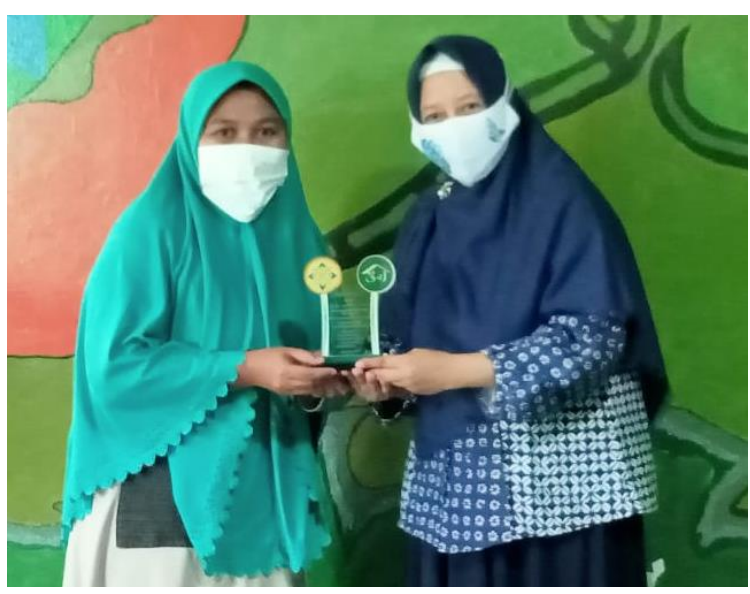

Gambar 4. Pemberian kenang-kenangan oleh Bu Jeni Andriani kepada kak Sisca selaku pengurus Yayasan Alabqo Amanah

\section{SIMPULAN}

Motivasi memegang peranan yang penting dalam proses belajar. Apabila guru dan orang tua dapat memberikan motivasi yang baik pada siswa atau anaknya, maka dalam diri siswa atau anak akan timbul dorongan dan 15asrat untuk belajar lebih baik. Memberikan motivasi yang baik dan sesuai, maka anak dapat menyadari akan manfaat belajar dan tujuan yang hendak dicapai dengan belajar tersebut. Motivasi belajar juga diharapkan mampu menggugah semangat belajar, terutama bagi para siswa yang malas belajar sebagai akibat pengaruh negative dari luar diri siswa.Berdasarkan definisi-definisi para ahli, maka motivasi belajar adalah dorongan atau 15asrat kemauan untuk melaksanakan kegiatan belajar dalam rangka mencapai tujuan.

Seorang Guru hanya sebagai fasilitator, motivator dan inspirator dari proses kegiatan belajar mengajar di kelas, sehingga semua kualitas dari dalam diri anak-anak didiknya, akan terbuka. Semua kreativitas terletak di dalam diri anak-anak didik, Keterlibatan jiwa seorang murid dalam suatu kegiatan belajar mengajar, akan memberikan motivasi kuat kepada mereka. Anak-anak didik kita akan merasa dirinya berharga untuk melakukan sesuatu yang tidak mungkin menjadi mungkin.

\section{Ucapan Terimakasih}

Ucapan terimakasih atas terlaksananya kegiatan pengabdian ini disampaikan kepada:

1. Universitas Pamulang.

2. Dekan Fakultas Ekonomi Universitas Pamulang.

3. Kepala Program Studi Manajemen yang telah memberikan persetujuan dan motivasi dalam terlaksananya kegiatan ini.

4. Jeni Andriani, S.S., S.E., M.M. selaku dosen pembimbing dalam program PKM mahasiswa.

5. Ketua dan Pengurus Yayasan Alabqo Amanah Marwah

6. Rekan-rekan mahasiswa Univeristas Pamulang

7. Berbagai pihak yang membantu dalam terlaksananya kegiatan ini.

\section{DAFTAR PUSTAKA}

https://www.google.com/search?q=motivasi + b elajar+adalah\&rlz=1C1CHBD_idID925I D925\&oq=motivas\&aqs $=$ chrome.0.69i5 9j69i57j35i39j0i43314j69i61.3797j0j7\& sourceid $=$ chrome $\&$ ie $=U T F-8$ 
https://www.kajianpustaka.com/2013/04/motiv asi-

elajar.html\#: :text=Motivasi\%20belajar $\%$ 20adalah

$\% 20$ keseluruhan $\% 20$ daya,Sardiman $\% 2$ C\%201986\%3A\%2075).

https://www.google.com/search?q=motivasi+a dalah\&rlz=1C1CHBD_idID925ID925\& $\mathrm{oq}=$ motivasi + adalah $\&$ aqs $=$ chrome. $0.0 \mathrm{i} 4$ 33j016j69i60.3256j0j7\&sourceid=chrom $\mathrm{e} \& \mathrm{ie}=\mathrm{UTF}-8$

https://www.academia.edu/39221047/Karya_il miah

http://eprints.uny.ac.id/21859/6/BAB\%20II.pd $\mathrm{f}$

https://www.papermakalah.com/2017/10/maka lah-motivasi-belajar.html 